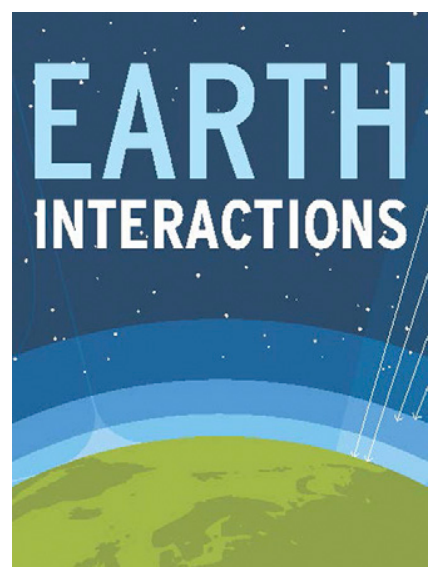

(C) 2018 American Meteorological Society. For information regarding reuse of this content and general copyright information, consult the AMS Copyright Policy (www.ametsoc.org/PUBSReuseLicenses).

\title{
Characteristics of Ethiopia Air Chemistry and Its Meteorological Context
}

\section{Mark R. Jury ${ }^{\mathrm{a}}$}

University of Zululand, KwaDlangezwa, South Africa, and Physics Department, University of Puerto Rico, Mayagüez, Puerto Rico

Received 9 May 2017; in final form 20 March 2018

\begin{abstract}
The concentration of trace gases and aerosols in Ethiopia is poorly characterized due to a limited history of surface measurements. Here, satellite measurements and model estimates of atmospheric composition are employed to understand space-time distributions in the period 2000-16. Methane $\left(\mathrm{CH}_{4}\right)$ and carbon monoxide $(\mathrm{CO})$ display high concentrations over the highlands and provide a focus for analysis of monthly and daily data. $\mathrm{CH}_{4}$ emissions from livestock peak at the beginning of the dry season, while $\mathrm{CO}$ from biomass burning rises at the end of the dry season. The seasonal cycle of dust, aerosol optical depth (AOD), and $\mathrm{CO}_{2}$ is inversely related with $\mathrm{CH}_{4}$, while $\mathrm{CO}$ closely follows sensible heat flux, thus linking drying and rural biomass burning. Stable easterly flow in the dry season accumulates local emissions, so near-surface concentrations of $\mathrm{CO}$ and $\mathrm{CH}_{4}$ are high then. The weather pattern underlying an episode of high nitrogen dioxide $\left(\mathrm{NO}_{2}\right)$ concentrations was studied. In addition to a stable lapse rate and dry anticyclonic weather, midtropospheric subsidence was related to intrusion of the northern subtropical jet stream on 24-26 December 2010. The wind shadow was cast by the Rift Escarpment limited dispersion, particularly with the dry, stable weather conditions. A key outcome of this work is that $\mathrm{CH}_{4}$ concentrations

\footnotetext{
${ }^{a}$ Corresponding author: Mark R. Jury, mark.jury@upr.edu
}

DOI: $10.1175 /$ EI-D-17-0009.1 
Earth Interactions - Volume 22 (2018) - Paper No. 12 • Page 2

over Ethiopia are high in global context and have increased $>0.1$ ppm from 2002 to 2016; hence, there is a need to improve livestock management and production efficiency.

KEYWORDS: Africa; Greenhouse gases; Orographic effects; Remote sensing

\section{Introduction}

\subsection{Background}

Greenhouse gas (GHG) emissions from agriculture and land-use contribute about one-quarter of global anthropogenic emissions (FAOSTAT 2016). Tropical subregions of Africa are major contributors of carbon dioxide $\left(\mathrm{CO}_{2}\right)$, carbon monoxide $(\mathrm{CO})$, black carbon $(\mathrm{BC})$, and nitrogen dioxide $\left(\mathrm{NO}_{2}\right)$ (Piketh et al. 1999; Jury 2000; Arino et al. 2012; Krotkov et al. 2016). Together with ozone $\left(\mathrm{O}_{3}\right)$ and methane $\left(\mathrm{CH}_{4}\right)$ emissions from biomass burning and livestock production, respectively, the GHG longwave radiation absorbers are likely to increase in the future (Dentener et al. 2005; Lamarque et al. 2010; Andreae and Ramanathan 2013). Hence, there is a need to better quantify trace gas concentrations over tropical Africa, as well as their sources and distribution in space and time. Emission estimates and inventories from rural agricultural sources have uncertainties that can be resolved via satellite observations and weather models incorporating dispersion. Unlike in situ point measurements, satellite observations provide useful information on regional-scale GHG concentrations (Bergamaschi et al. 2007; van der A et al. 2008; Marais et al. 2014a,b).

Ethiopia's $\sim 100$ million people subsist on a gross domestic product of $\sim \$ 54$ billion (in 2015) and have low energy consumption (4290 MW) and small urban industrial emissions (World Bank 2016). Electricity does not reach $73 \%$ of the population, so rural households depend on gas and fuelwood for cooking and heating. Additionally, $88 \%$ of the population live in highlands above $1500 \mathrm{~m}$, which covers $44 \%$ of the country (Desalegn et al. 2014; World Bank 2016), with mean minimum temperature $<15^{\circ} \mathrm{C}$ (cf. Figure 1a). The United Nations Development Program (UNDP 2011) and the Food and Agriculture Organization Statistical Database (FAOSTAT 2016) GHG emission estimates are 50\%-60\% from agriculture, $19 \%-37 \%$ land-use, 3\%-7\% urban, 3\%-6\% waste, 3\% transport, $2 \%-$ $3 \%$ energy, and 2\%-3\% industry. Agricultural burning of $\sim 30$ billion kg covers $\sim 4.6$ Mha of Ethiopia (Giglio et al. 2003; cf. Figure 3a below). Ethiopia's 132 million livestock (in 2015) account for $20 \%$ of agriculture value and release significant quantities of GHG and aerosols (Teferi et al. 2013). Cattle comprise $>50 \%$ of livestock (USAID 2013) and emit $>30 \mathrm{~kg}$ of $\mathrm{CH}_{4}$ per annum per head (Broucek 2014 ). Forests cover $<12 \%$ of the country, savannah $>65 \%$, and croplands $>16 \%$ (FAS 2016). Soil bacteria and seasonal lightning release nitrates (Yienger and Levy 1995; Christian et al. 2003), but there are few volcanic or industrial sulfate sources. The dense vegetation, biomass burning, and livestock emit volatile organic compounds and $\mathrm{CH}_{4}$ that react to form fine aerosols, ozone, and formaldehyde (Marais et al. 2014a).

Satellites have provided estimates of atmospheric particulates since 1980 (Burrows et al. 2011). Recent advances in passive remote sensing, such as NASA's Atmospheric Infrared Sounder (AIRS) and Ozone Monitoring Instrument (OMI), 

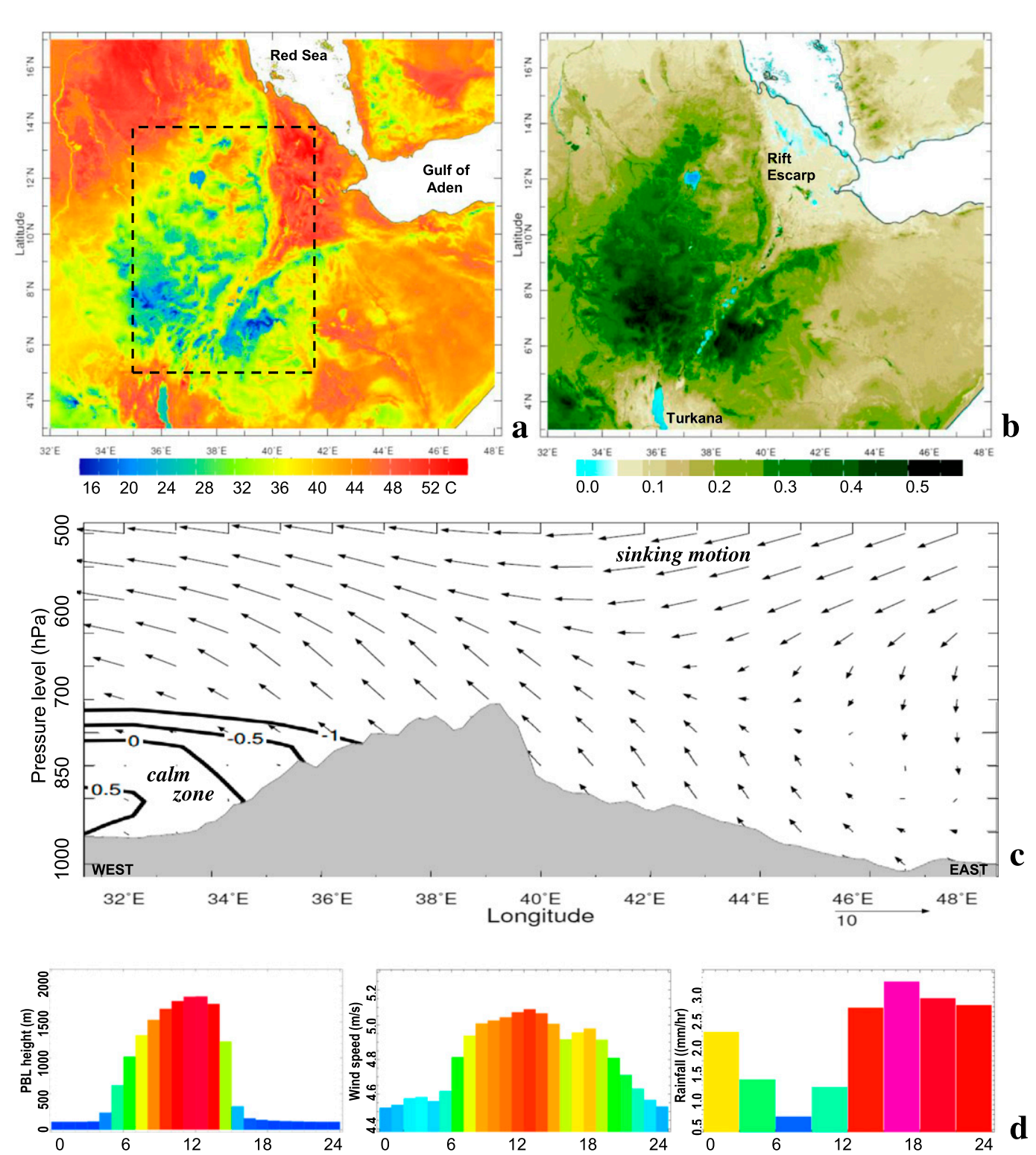

Figure 1. Mean maps averaged 2003-15 of (a) MODIS daytime land-surface temperature and index area (dashed), (b) MODIS color vegetation index, and (c) MERRA zonal circulation $(W \times 70)$ in vertical cross section averaged $6^{\circ}-$ $13^{\circ} \mathrm{N}$ with topography and calm zone $\mathrm{U}$ contoured. (d) Index area mean diurnal cycle of (left to right) MERRA hourly PBL height and surface wind speed and 3-hourly CMORPH rainfall. Local time is UTC +3 .

enable the mapping of near-surface GHG distributions $(2003+)$. Trace gas estimation depends on ultraviolet absorption $(\lambda: 0.31-0.46 \mu \mathrm{m})$ (Krotkov et al. 2006), while aerosols $>0.1-\mu \mathrm{m}$ diameter and carbon gases induce near-infrared absorption $(\lambda: 0.5-7.6 \mu \mathrm{m})$. Satellite retrievals for Ethiopia must contend with seasonal obscuration by Saharan dust and thick clouds. Rural and biogenic emissions are 
Earth Interactions - Volume 22 (2018) • Paper No. 12 • Page 4

diffused and may be insensitive to wind trajectory and planetary boundary layer (PBL) height, compared with their urban industrial counterparts. In addition to satellite retrievals, the Modern-Era Retrospective Analysis for Research and Applications, version 2 (MERRA-2), reanalysis model (Molod et al. 2015) with air chemistry assimilation (Rienecker et al. 2016) helps quantify dispersion conditions over Ethiopia. Although little in situ data on urban industrial and agricultural emissions are available, source inventories provide adequate information (CAIT 2016).

\subsection{Motivation and objectives}

Harmful air constituents can limit productivity through human respiratory complications and reduced resource yields (van Wesenbeeck et al. 2009; Fantaye 2016). Ethiopia experiences a mortality rate of 57/100 000 from air pollution exposure (WHO 2016), with total pollution-related deaths of 129000 in 2015 (Landrigan et al. 2018). The country is a major source of $\mathrm{CH}_{4}$ emissions (FAOSTAT 2016).

The central objective of this work is to characterize the near-surface air chemistry at daily to seasonal time scales by analysis of satellite- and model-estimated trace gases, particulates, and meteorological conditions over the Ethiopian highlands. Scientific questions include the following:

(i) What are the characteristic patterns and seasonality of near-surface air constituents?

(ii) Which are regionally imported versus locally generated?

(iii) How are local emissions transported and dispersed?

(iv) Which meteorological factors affect Ethiopia's air chemistry at annual and daily time scales?

\section{Data and methods}

Anticipating rural agricultural emissions from the Ethiopian highlands, our study of air chemistry covers $3^{\circ}-17^{\circ} \mathrm{N}, 31.5^{\circ}-48^{\circ} \mathrm{E}$, and the subset "index" area for the time series is $5^{\circ}-14^{\circ} \mathrm{N}, 35^{\circ}-41.5^{\circ} \mathrm{E}$ (Figure 1a). The geographic focus excludes the lowlands surrounding Ethiopia, where vegetation fraction and agricultural emissions are half the highlands. Maps of MODIS fire counts (Justice et al. 2002), livestock density (Robinson et al. 2014), and lightning strikes (Cecil et al. 2015) yield insights on emission sources. Short-lived trace gas estimates from the OMI satellite include cloud-screened tropospheric $\mathrm{NO}_{2}$ (Bucsela et al. 2013; Lamsal et al. 2014) and (low level) PBL sulfur dioxide ( $\mathrm{SO}_{2}$; Krotkov et al. 2006) interpolated to $25-\mathrm{km}$ resolution from October 2004 to December 2015. Multilevel trace gas estimates of $\mathrm{CH}_{4}, \mathrm{CO}, \mathrm{CO}_{2}$, and $\mathrm{O}_{3}$ derive from the AIRS satellite (Maddy et al. 2008; Xiong et al. 2008; Yurganov et al. 2008; Warner et al. 2010; Thonat et al. 2012; Levy et al. 2013) at 100-km resolution from September 2002 to December 2015, as daytime retrievals averaged in the $850-700-h P a$ layer. MISR satellite $0.55 \mu \mathrm{m}$ aerosol optical depth (AOD) at $50-\mathrm{km}$ resolution describes mineral dust intrusions from adjacent deserts. MERRA-2 air chemistry data (Molod et al. 2015) include monthly near-surface $\mathrm{SO}_{2}, \mathrm{BC}$, dust particulates $(<10 \mu \mathrm{m})$ and $\mathrm{O}_{3}$ concentration at $\sim 50-\mathrm{km}$ resolution from January 2000 to December 2015. The GEOS-5 system assimilates in situ and satellite observations, 
Earth Interactions - Volume 22 (2018) • Paper No. 12 • Page 5

Table 1. Datasets used in the analysis. All data are sourced from NASA Giovanni website, except as footnoted.

\begin{tabular}{|c|c|c|c|}
\hline Acronym & Name & Space, time resolution & Quantity \\
\hline AIRS & Atmospheric Infrared Sounder v6 & $\begin{array}{l}100 \mathrm{~km} \text {, twice daily } \\
\text { with gaps }\end{array}$ & $\begin{array}{l}\mathrm{CH}_{4}, \mathrm{CO}, \mathrm{O}_{3} \\
\quad 925-500-\mathrm{hPa} \text { layers }\end{array}$ \\
\hline CALIPSO & $\begin{array}{l}\text { Cloud-Aerosol Lidar and Infrared } \\
\text { Pathfinder Satellite Observations L3 }\end{array}$ & $\begin{array}{l}\sim 10 \mathrm{~km} \text { at zenith, } \\
\text { weekly pass }\end{array}$ & Fine aerosol density \\
\hline $\mathrm{GFS}^{\mathrm{a}}$ & $\begin{array}{l}\text { Global Forecast System, operational } \\
\text { weather data }\end{array}$ & $50 \mathrm{~km}, 3$-hourly & $\begin{array}{l}\text { Meteorology for } \\
\text { HYSPLIT model }\end{array}$ \\
\hline${\text { HYSPLIT }{ }^{\mathrm{a}}}$ & $\begin{array}{l}\text { Hybrid Single Particle Lagrangian } \\
\text { Integrated Trajectory Model }\end{array}$ & $\sim 10 \mathrm{~km}$, within plume & $\begin{array}{l}\text { Forward dispersion } \\
\text { simulation }\end{array}$ \\
\hline LIS & $\begin{array}{l}\text { Lightning Imaging Sensor } \\
\text { (TRMM satellite) }\end{array}$ & $50 \mathrm{~km}$ & $\begin{array}{l}\text { Flash density } \\
\text { climatology }\end{array}$ \\
\hline MERRA-2 & $\begin{array}{l}\text { Modern-Era Retrospective Analysis } \\
\text { for Research and Applications, v2, } \\
\text { with GEOS-5 air chemistry v5 }\end{array}$ & $\sim 50 \mathrm{~km}$, daily, monthly & $\begin{array}{l}\mathrm{SO}_{2}, \mathrm{O}_{3}, \mathrm{BC}, \text { fine dust, } \\
\text { meteorology }\end{array}$ \\
\hline MISR & $\begin{array}{l}\text { Multiangle Imaging } \\
\text { Spectroradiometer v4 }\end{array}$ & $50 \mathrm{~km}$, daily with gaps & $\begin{array}{l}\text { Aerosol index of fine } \\
\text { dust }\end{array}$ \\
\hline MODIS $^{\mathrm{b}}$ & $\begin{array}{l}\text { Moderate Resolution Imaging } \\
\text { Spectroradiometer (Terra) }\end{array}$ & $\begin{array}{l}\sim 8 \mathrm{~km}, \text { multiday } \\
\text { composite }\end{array}$ & $\begin{array}{l}\text { Land-surface temperature, } \\
\text { vegetation }\end{array}$ \\
\hline OMI & $\begin{array}{l}\text { Ozone Monitoring Instrument } \\
\qquad(A U R A) \mathrm{v} 3\end{array}$ & $\begin{array}{l}25 \mathrm{~km} \text {, twice daily with } \\
\text { gaps }\end{array}$ & $\begin{array}{l}\text { Near-surface } \mathrm{NO}_{2} \\
\text { and } \mathrm{SO}_{2}\end{array}$ \\
\hline
\end{tabular}

${ }^{a}$ Sourced from NOAA ARL Ready website.

b Sourced from IRI Climate Library website.

combined with emission inventories (Buchard et al. 2015; da Silva et al. 2015). The satellite inputs are incremental and start with tropospheric O3 and AOD in 1980 (Torres et al. 2002), CO in the 1990s, and tropospheric trace gases in the 2000s. The above references provide information on how the individual satellites retrieve air chemistry measurements. Algorithms that convert radiometer responses to measurements depend on in situ validations in a variety of environments. Similar work in the more industrialized South Africa (Jury 2017) has determined that satellite $\mathrm{SO}_{2}$ estimates are ambiguous, whereas other variables show agreement with in situ measurements and inventory-based model simulations.

The MERRA-2 meteorological data employed here include 850 - and 775-hPa air temperature and lapse rate $(d T / d z), 850-700-\mathrm{hPa}$ wind components, $850-775-\mathrm{hPa}$ relative divergence, $700-\mathrm{hPa}$ specific humidity, $500-\mathrm{hPa}$ geopotential height and vertical motion, and PBL height, calculated as the depth of surface-induced turbulence. "Near surface" averages in the 850-700-hPa layer represent transport and dispersion over the Ethiopian highlands. Additional data include satellite color vegetation fraction at $8-\mathrm{km}$ resolution (NDVI; Tucker et al. 2005) and multisatellite estimated rainfall at 25-km resolution (CMORPH; Joyce et al. 2004). Table 1 summarizes the datasets, acronyms, and characteristics.

Time series of index area-averaged monthly and daily AIRS, MISR, and OMI satellite data and MERRA-2 model data were formulated. Gaps in daily satellite retrievals 2003-15 (from passive polar-orbiting radiometers) were in-filled by calculation of a 3-day running maximum. Statistical analyses utilized Pearson product-moment cross-correlation of air constituents and meteorology for the mean seasonal cycle and continuous daily fluctuations. Given the temporal filtering and serial autocorrelation, 192 months reduced to 4 degrees of freedom, and 4748 
Earth Interactions - Volume 22 (2018) • Paper No. 12 • Page 6

days reduced to $\sim 30$ degrees of freedom, yielding statistical thresholds for $90 \%$ confidence of $|0.7|$ monthly and $|0.3|$ daily. Comparisons of global and local averages were made for seasonal cycles of $\mathrm{CO}_{2}$ and $\mathrm{CH}_{4}$.

To understand the air chemistry concentration, transport, and dispersion, seasonal mean maps were calculated for $\mathrm{BC}, \mathrm{CH}_{4}, \mathrm{CO}, 700-\mathrm{hPa}$ winds, sinking motion, surface temperature, and rainfall. Vertical cross-sections of mean AIRS satellite $\mathrm{CO}, \mathrm{CH}_{4}$, and $\mathrm{O}_{3}$ were analyzed up to $500 \mathrm{hPa}$, and the diurnal cycle of MERRA-2 hourly PBL height, near-surface wind speed, and 3-hourly CMORPH rainfall was calculated. Vertical cross-sections of the MERRA-2 meridional circulation and wind vorticity were analyzed for key features, such as the equatorial trough and subtropical jet.

The daily time series were ranked, and MERRA-2 near-surface winds were analyzed for the peak episode of 24-26 December 2010, when $\mathrm{NO}_{2}$ and other trace gas concentrations were high. The atmospheric dispersion of a continuous virtual source at $9^{\circ} \mathrm{N}, 37^{\circ} \mathrm{E}, 100 \mathrm{~m}$ in the period $24-26$ December 2010 was simulated by the HYSPLIT model underpinned with GFS weather data and by radiosonde profiles from southwestern Arabia. Aerosol density cross sections were obtained on 24 December 2010 from the Cloud-Aerosol Lidar and Infrared Pathfinder Satellite Observations (CALIPSO; Winker et al. 2007). Each air constituent has certain units: MERRA-2 variables are $\mathrm{kg} \mathrm{m}^{-3}$ (typically $\times 10^{-9}$ ); AIRS O3, $\mathrm{CH} 4$, and CO is ppm or $\mu \mathrm{g} \mathrm{m}^{-3}$ (typically $\times 10^{-8}$ ); and OMI NO2 is $\mathrm{cm}^{-2}\left(\times 10^{16}\right)$.

The research outcomes subdivide into (i) climatology and seasonal cycle, (ii) temporal statistics and relative influence, and (iii) daily air chemistry fluctuations and scenario of maxima. The scope of work excludes validations due to unavailability of local in situ measurements. Work elsewhere has sought to minimize uncertainties in satellite trace gas retrievals through algorithm refinement (Maddy et al. 2008; Xiong et al. 2008; Yurganov et al. 2008; Jury 2017). With regard to $\mathrm{CH}_{4}$, Bergamaschi et al. (2007) note $\pm 1.5 \%$ uncertainty in satellite retrievals and \pm 3 -ppb uncertainty in surface measurements. Frankenberg et al. (2006) found that "cloud screening" reduces systematic errors below 3\% for satellite retrievals of constituents such as $\mathrm{CH}_{4}, \mathrm{CO}_{2}$, and $\mathrm{NO}_{2}$.

\section{Results}

\section{1. Climatology and seasonal cycle}

MODIS satellite data averaged 2003-15 (Figures 1a,b) characterize the highland climate: cool land temperatures $\left(\sim 25^{\circ} \mathrm{C}\right)$ and moderate vegetation fraction $(\sim 0.4)$. The mean zonal circulation (Figure 1c) reveals winds from the east with a rising component in the low levels and a sinking component in the upper levels. There is a wind shadow just west of the Rift Escarpment, where trace gases tend to accumulate. The mean diurnal cycle averaged over the highlands area (Figure 1d) displays large-amplitude changes in PBL height $(120-1800 \mathrm{~m})$ and rainfall $\left(0.8-3.6 \mathrm{~mm} \mathrm{~h}^{-1}\right)$ and modest changes of wind speed $\left(4-5 \mathrm{~m} \mathrm{~s}^{-1}\right)$. The daytime satellite overpass corresponds with a deep boundary layer prior to moist convection. Daytime near-surface winds tend to converge onto the highlands (cf. Figure 6c; also Jury 2016) and tend to limit (enhance) horizontal (vertical) dispersion. 

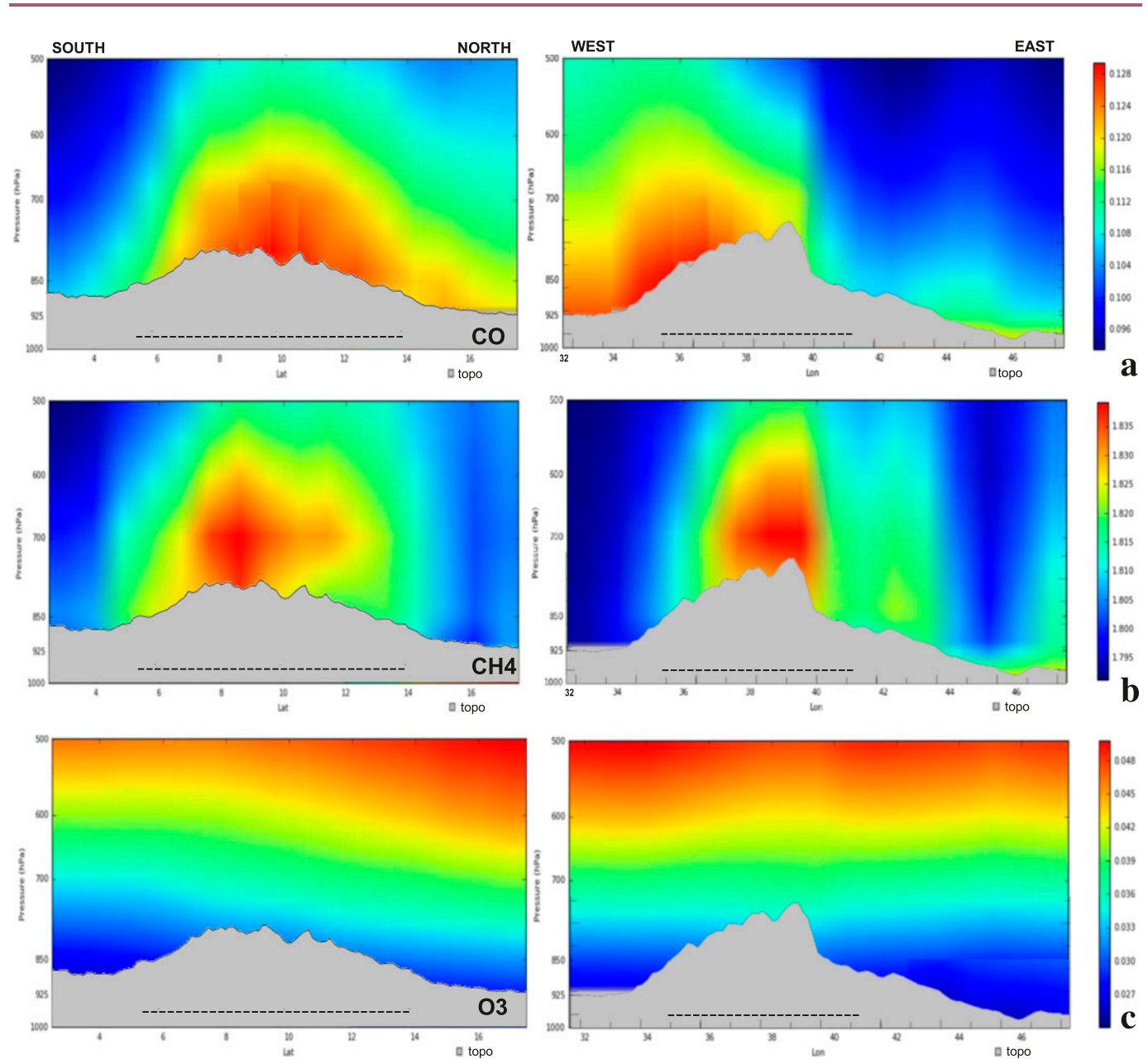

Figure 2. Mean 2003-15 vertical cross-sections (left: S-N avg $35^{\circ}-41.5^{\circ} \mathrm{E}$; right: W-E avg $6^{\circ}-13^{\circ} \mathrm{N}$ ) of AIRS daytime (a) $\mathrm{CO}$, (b) $\mathrm{CH}_{4}$, and (c) $\mathrm{O}_{3}$, all in ppm with topography. The index area is dashed.

The 2003-15 mean north-south and east-west cross-sections (Figures 2a-c) of AIRS CO, $\mathrm{CH}_{4}$, and $\mathrm{O}_{3}$ characterize the vertical structure of trace gases over Ethiopia, while emission sources (Figures 3a-c) provide context. CO (Figure 2a) displays a lowlevel maximum over the western highlands $\left(\sim 10^{\circ} \mathrm{N}, 36^{\circ} \mathrm{E}, 850 \mathrm{hPa}\right)$ consistent with biomass burning (cf. Figure 3a) and westward transport, forming the African smoke plume (Giglio et al. 2003). $\mathrm{CH}_{4}$ (Figure 2b) also displays a low-level maximum over the highlands $\left(\sim 9^{\circ} \mathrm{N}, 39^{\circ} \mathrm{E}, 700 \mathrm{hPa}\right)$ where the livestock are located (cf. Figure $\left.3 \mathrm{~b}\right)$. In contrast, $\mathrm{O}_{3}$ (Figure 2c) increases aloft and to the north, indicating photochemical production from more distant sources in the subtropics (Cooper et al. 2014). The mean climatology map for $\mathrm{NO}_{2}$ (Figure 3c) illustrates plumes extending westward from the highlands, attributable to biomass burning, lightning, and minor urban industrial sources (van der A et al. 2008). The $\mathrm{NO}_{2}$ plume emanating from the city of Addis Ababa (population 4.6 million in 2016) corresponds with in situ particulate concentrations up to $1 \mathrm{mg} \mathrm{m}^{-3}$ (Abate 2015; Tefera et al. 2016). 

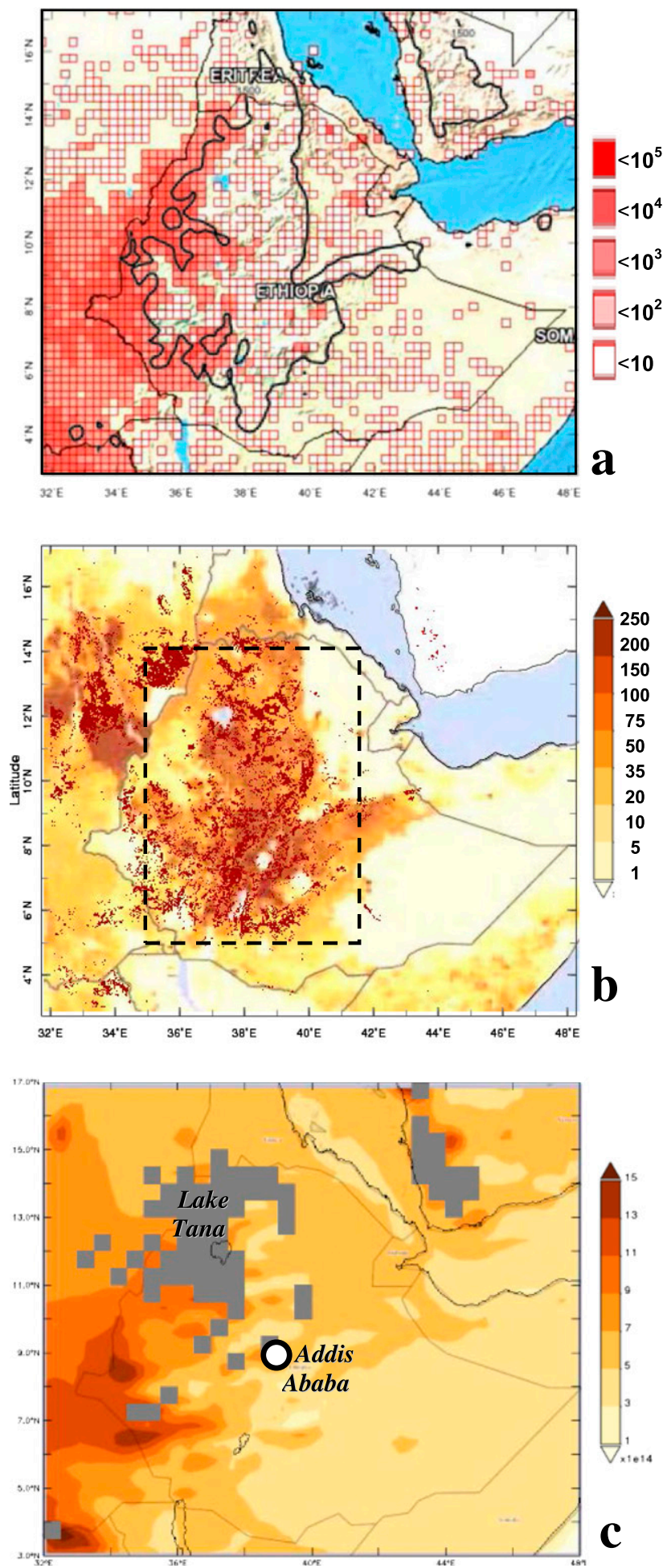

Figure 3. (a) Map of MODIS fire counts summed over 2003-15 with 1500-m elevation contour. (b) Livestock density (number per square kilometer; adapted from Wint and Robinson 2007) with index area (dashed). (c) OMI satellite tropospheric $\mathrm{NO}_{2}$ climatology 2005-16 number per square centimeter) with LIS satellite lightning flash density $>300 \mathrm{~km}^{-2}$ raster gray shaded. Largest city is shown as a circle. 

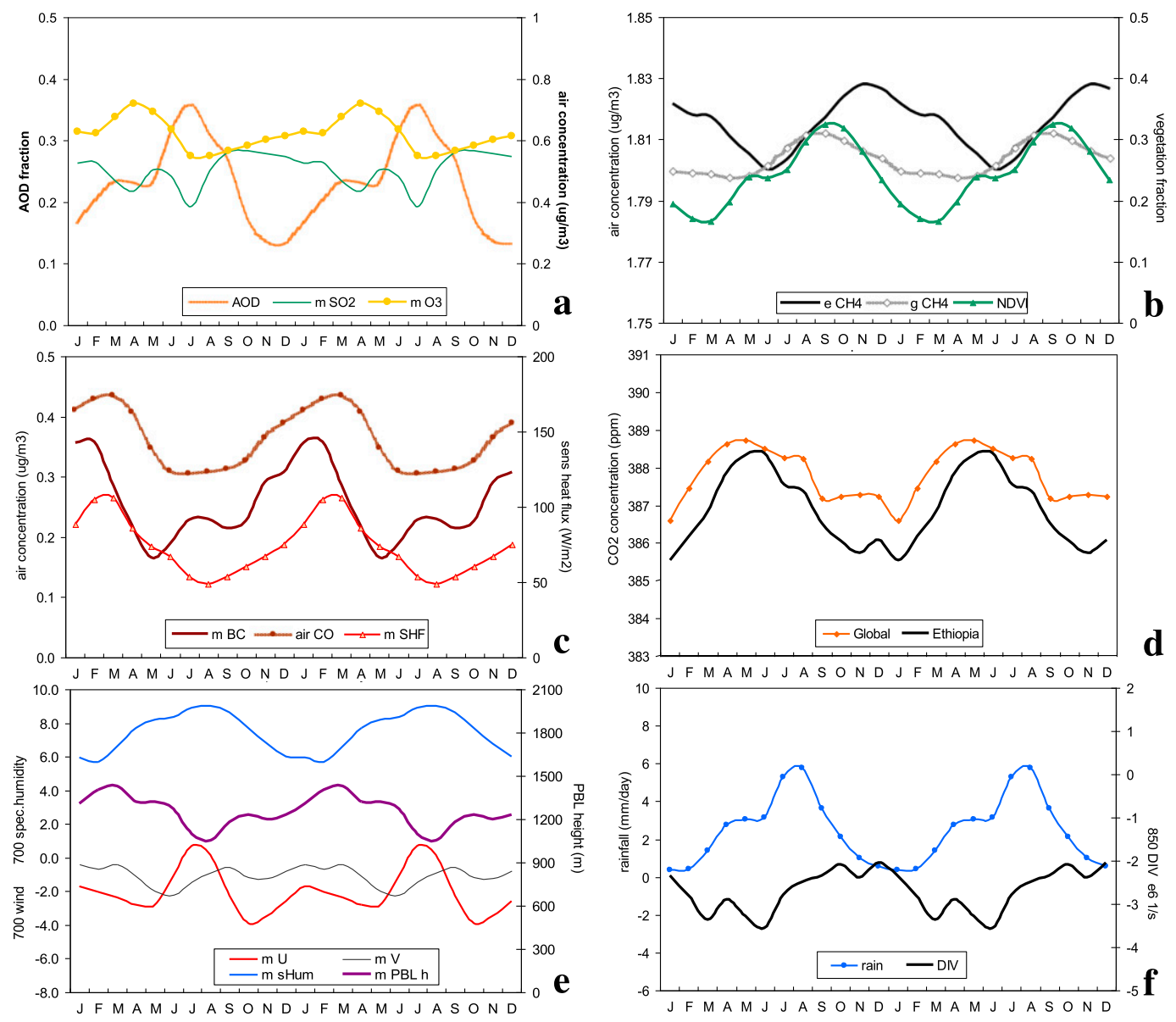

Figure 4. Mean seasonal cycle $(\times 2)$ within the index area of $(a)$ MERRA air constituents, (b) AIRS methane and vegetation, (c) MERRA BC, AIRS CO, and SHF, (d) AIRS global and local $\mathrm{CO}_{2}$, (e) MERRA meteorological variables, and $(f)$ CMORPH rainfall and near-surface wind divergence. Seasonal cycle correlations are listed in Table 2.

The Ethiopian highland mean seasonal cycle (Figures 4a-f) displays low amplitude for $\mathrm{SO}_{2}, \mathrm{O}_{3}$, PBL height, and $V$ wind and high amplitude for other variables. The climatic insensitivity of $\mathrm{SO}_{2}, \mathrm{O}_{3}$, and dust (AOD) suggests inward transport from distant sources (Knippertz and Todd 2012). PBL height is flat because of the offsetting effect of moist convection during summer, while the northsouth shift of the equatorial trough exerts minimal influence on $V$ winds due to orography. Among those variables with large seasonal cycle, $\mathrm{CH}_{4}$ lags vegetation and maximizes in October-December, while the $\mathrm{BC}$ and $\mathrm{CO}$ peak in JanuaryFebruary with biomass burning. The Ethiopian area-averaged $\mathrm{CH}_{4}$ is above the global average $\mathrm{CH}_{4}$ from November to March (cf. Figure 4b). Meteorological variables with large but narrow seasonal range include rainfall and humidity (JulyAugust peak). Wind convergence rises to a maximum in June, whereas westward transport ( $-U$ wind) displays a broad peak in the October-May dry season. 
Earth Interactions - Volume 22 (2018) • Paper No. 12 • Page 10

Ethiopia $\mathrm{CO}_{2}$ values are 1-2 ppm below global due to small industrial emissions, whereas $\mathrm{CH}_{4}$ values are 2-3 ppm above global due to agricultural emissions.

Among the seasonal cycle correlations in Table 2, AOD, dust, and $\mathrm{CO}_{2}$ are inversely related with $\mathrm{CH}_{4}$. The $\mathrm{BC}$ increases in dry weather, and $\mathrm{CO}$ follows sensible heat flux (SHF), indicating that drying is linked with biomass burning. The wind variables reveal transport and mixing influences: northerly winds $(-V)$ increase $\mathrm{CO}_{2}$, southerlies increase $\mathrm{BC}$ concentrations, westerly winds bring dust (AOD), and easterlies $(-U)$ raise $\mathrm{CO}, \mathrm{CH} 4$, and $\mathrm{O} 3$ concentrations. These links suggest horizontal advection as the main driver. NDVI is negative correlated with SHF, CO, and PBL height, which rise in the dry season.

\subsection{Seasonal features}

The seasonal distribution of near-surface trace gases is illustrated in Figures 5a-c. Having outlined the mean seasonal cycle, both $\mathrm{CO}$ and $\mathrm{BC}$ show high concentration over the southwest highlands in the December-February season and low concentration during the wet season. The $\mathrm{CH}_{4}$ shows a persistent livestock "footprint" at higher elevations with a maximum at the end of the growing season (September-November) over the north-central highlands.

The seasonal atmospheric circulation (Figures 6a-d) is dominated by upperlevel anticyclonic vorticity (and subsidence) imparted by the subtropical jet stream, especially in the December-February season. By March-May, a shallow overturning circulation develops in the south as the subtropical jet weakens. Northeasterly flow shifts to easterly and surface air temperatures rise in March-May before the wet season. The equatorial trough and its cyclonic vorticity push northward to the highlands in the June-August season. Increasing rainfall and wet deposition reduces trace gas and aerosol concentrations, except for $\mathrm{CH}_{4}$. The meridional overturning circulation weakens in the September-November season, and near-surface easterly flow is reestablished.

Considering the dry-season map (Figure 6a), a key feature is the horizontal diffluence of easterly flow reaching the Rift Escarpment. Subtropical troughs channel flow into the Red Sea and draw air from the northern highlands, while easterlies pass across the southern highlands and Turkana Valley. North-south bands of subsiding air create standing waves and a dry stable layer $(d T / d z$ $-5^{\circ} \mathrm{C} \mathrm{km}^{-1}$ ). The Froude number $\mathrm{Fr}=U / N h$ (wind speed divided by buoyancy index and mountain height; Reisner and Smolarkiewicz 1994) falls below 0.3, so a wind shadow forms west of the Rift Escarpment and accumulates trace gases.

\subsection{Intraseasonal variability}

Daily time series of near-surface satellite trace gases are given in Figures $7 \mathrm{a}-\mathrm{c}$. Of concern is the rising trend of daily $\mathrm{CH}_{4}$ that accounts for a remarkable $43 \%$ of total variance related to the concomitant growth of human and livestock populations. The seasonal cycle is of similar amplitude to episodic fluctuations, suggesting steady emissions influenced more by slowly varying vegetation cover than dispersion conditions. In contrast, $\mathrm{CO}$ exhibits a weak decline and large episodic fluctuations (from biomass burning). $\mathrm{NO}_{2}$ episodes far exceed the seasonal cycle, 


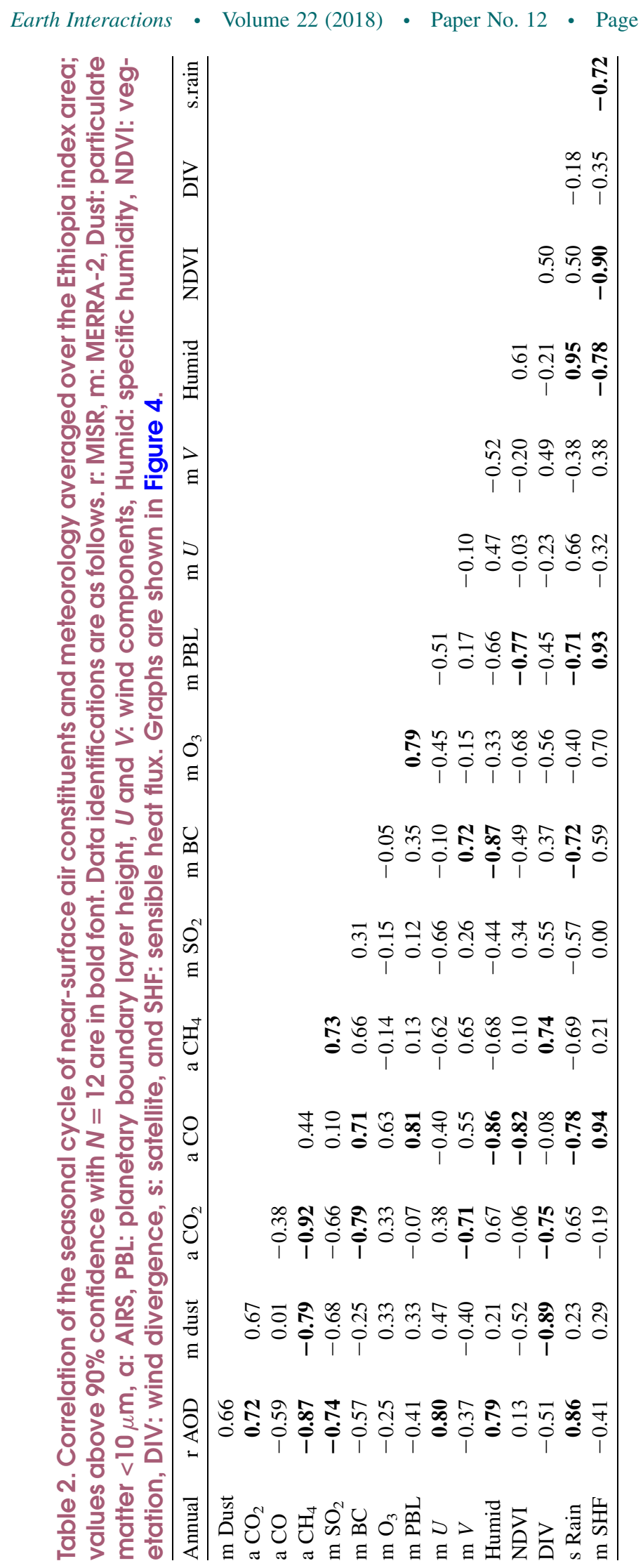




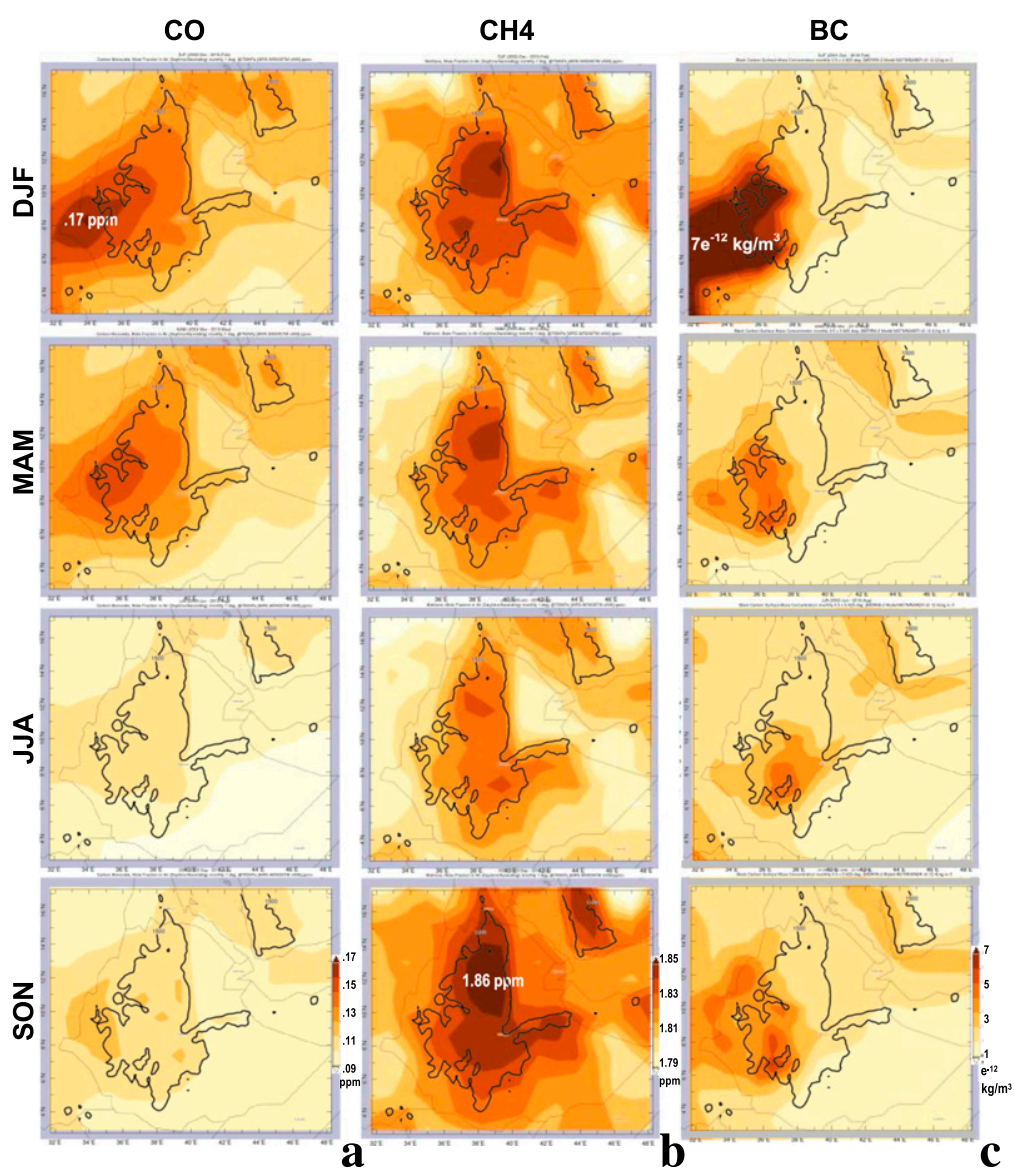

Figure 5. Seasonal mean maps of daytime near-surface (a) $\mathrm{CO}$, (b) $\mathrm{CH}_{4}$, (c) $\mathrm{O}_{3}$, and (d) BC. Each column has the same scale, and maximum values are labeled; $1500-m$ elevation is contoured.

particularly in the dry seasons of 2010-11 and 2014-15. Spikes in the $\mathrm{NO}_{2}$ record tend to grow with time and relate to weather conditions (cf. section 3.4.), yet the overall trend is minimal.

Table 3 lists the daily correlations and shows interdependence of near-surface $\mathrm{CO}$ and $\mathrm{NO}_{2}(r=+0.50)$ and $\mathrm{CO}$ and satellite $\mathrm{O}_{3}(+0.70)$. The correlation of model versus satellite $\mathrm{O} 3$ is disappointing $(+0.23)$, likely because retrievals are tuned for the upper troposphere. CO relates to humidity and dewpoint temperature $(-0.52,-0.55$ drier $)$, lapse rate $(+0.45$ stable $)$, and OLR $(+0.44$ warmer $) . \mathrm{NO}_{2}$ mirrors the $\mathrm{CO}$ meteorology correlations; both show negative association with vorticity and $U$ wind. Although anticyclonic easterly winds could draw air pollution from the Arabian Peninsula (Farahat 2016), most distribution maps (cf. Figures 2, 5) show low concentrations over the Red Sea and Gulf of Aden. Thus, we infer an accumulation of local emissions within the highlands wind shadow. $\mathrm{CH}_{4}$ shows relatively weaker meteorological influence, except for OLR $(+0.37$ warmer). Daily near-surface $\mathrm{O}_{3}$ from the model correlates with air temperature 


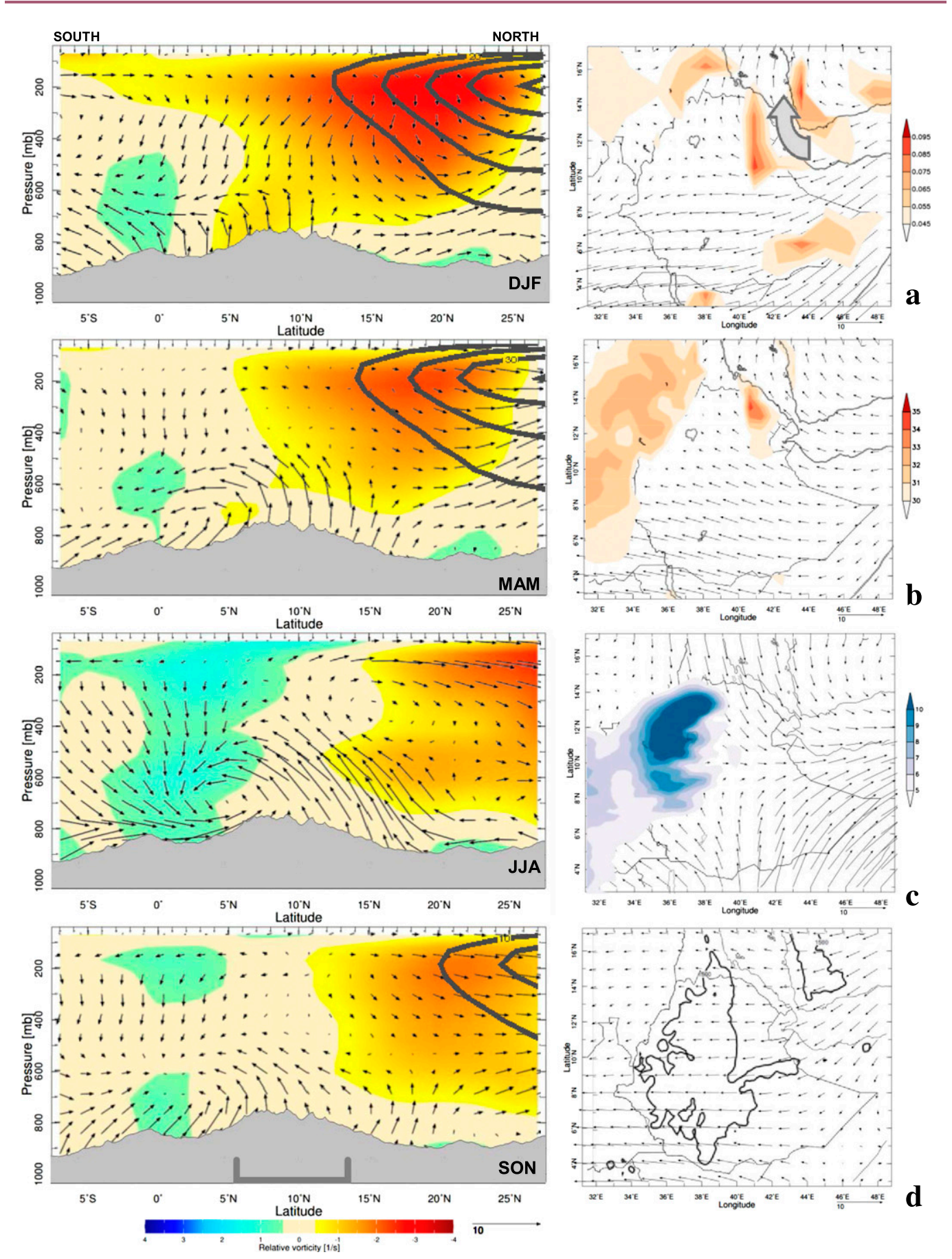

Figure 6. (left) Seasonal mean vertical cross sections averaged $35^{\circ}-41.5^{\circ} \mathrm{E}$ of wind vorticity (shaded $\times 10^{-5}$, anticyclonic negative orange), zonal wind (contours $>10 \mathrm{~m} \mathrm{~s}^{-1}$ ), and meridional circulation (vectors, $\mathrm{W} \times 60$ ) with topography; (lower left) index area bracket. (right) Seasonal mean maps of $(850-700 \mathrm{hPa})$ near-surface winds, with same scale. Map overlays (a) DJF: 700-hPa sinking motion $>0.045 \mathrm{~Pa} \mathrm{~s}^{-1}$ and flow channeling; (b) MAM: air temp $>30^{\circ} \mathrm{C}$; (c) JJA: CMORPH rainfall $>5 \mathrm{~mm}$ day $^{-1}$; and (d) SON: $1500-\mathrm{m}$ elevation contour. 

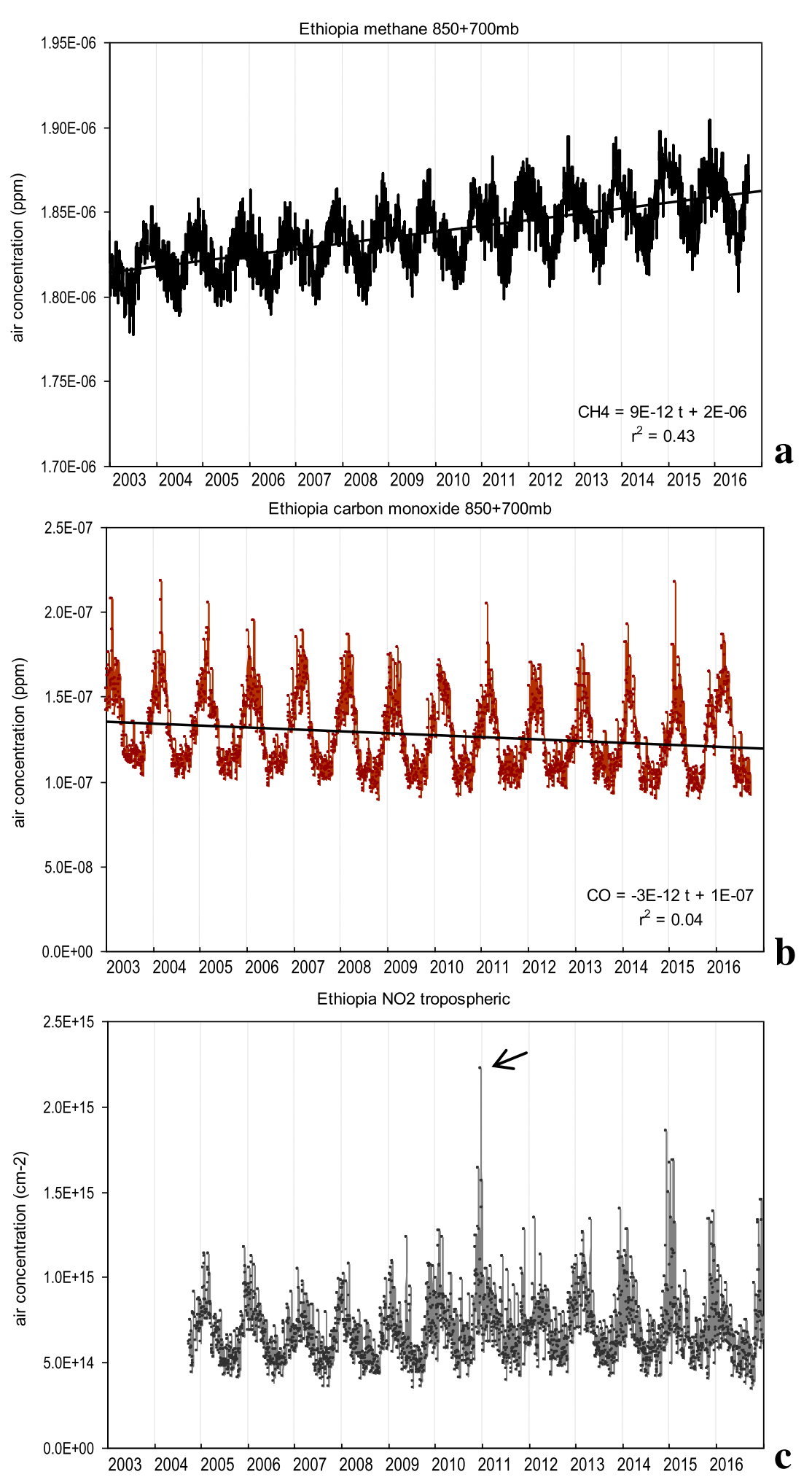

Figure 7. Daily time series of Ethiopia index area near-surface (a) AIRS $\mathrm{CH}_{4}$, (b) AIRS $\mathrm{CO}$, and (c) $\mathrm{OMI} \mathrm{NO}$, incorporating a 3-day running maximum. Linear trends are given in (a),(b); arrow points to case study in (c). 
Earth Interactions - Volume 22 (2018) • Paper No. 12 • Page 15

Table 3. Correlation of daily time series of near-surface air constituents and meteorology averaged over the Ethiopia index area; values above $90 \%$ confidence with $N=4748$ are in bold font. Data identification areas follows. O: OMI, T: 775-hPa air temperature, $d T / d z$ : lapse rate, OLR: satellite outgoing longwave radiation, Vort: wind vorticity (anticyclonic negative), and $T$ dew: surface dewpoint temperature. Duplicate items are consistent with Table 2. Scatterplots are shown in Figure 8.

\begin{tabular}{|c|c|c|c|c|c|c|c|c|c|c|c|c|}
\hline Daily & $\mathrm{a} \mathrm{CH}_{4}$ & $\mathrm{a} \mathrm{CO}$ & $\mathrm{o} \mathrm{NO}_{2}$ & $\mathrm{~m} \mathrm{O}_{3}$ & $\mathrm{a} \mathrm{O}_{3}$ & Humid & $\mathrm{m} U$ & $\mathrm{~m} T$ & $d T / d z$ & OLR & Vort & DIV \\
\hline $\mathrm{aCO}$ & -0.03 & & & & & & & & & & & \\
\hline $\mathrm{o} \mathrm{NO}_{2}$ & 0.23 & 0.50 & & & & & & & & & & \\
\hline $\mathrm{m} \mathrm{O}_{3}$ & -0.22 & 0.31 & 0.11 & & & & & & & & & \\
\hline $\mathrm{a} \mathrm{O}_{3}$ & 0.36 & 0.70 & 0.28 & 0.23 & & & & & & & & \\
\hline Humid & -0.19 & -0.52 & -0.38 & -0.13 & -0.55 & & & & & & & \\
\hline $\mathrm{m} U$ & -0.28 & -0.36 & -0.26 & -0.26 & -0.55 & 0.46 & & & & & & \\
\hline $\mathrm{m} T$ & -0.12 & 0.24 & 0.05 & 0.64 & 0.33 & -0.29 & -0.19 & & & & & \\
\hline$d T / d z$ & 0.11 & 0.45 & 0.32 & 0.13 & 0.28 & -0.32 & -0.44 & -0.08 & & & & \\
\hline OLR & 0.36 & 0.44 & 0.35 & 0.07 & 0.48 & -0.75 & -0.61 & 0.24 & 0.45 & & & \\
\hline Vort & -0.26 & -0.35 & -0.30 & 0.10 & -0.45 & 0.28 & 0.34 & 0.17 & -0.31 & -0.36 & & \\
\hline DIV & 0.33 & 0.22 & 0.28 & -0.11 & 0.18 & -0.37 & -0.54 & -0.17 & 0.37 & 0.55 & -0.44 & \\
\hline$T$ dew & -0.23 & -0.55 & -0.42 & -0.03 & -0.56 & 0.90 & 0.43 & -0.19 & -0.38 & -0.79 & 0.35 & -0.42 \\
\hline
\end{tabular}

$\left(+0.64\right.$ warmer), while $\mathrm{O}_{3}$ from the satellite relates to dry conditions. Figures $8 \mathrm{a}-\mathrm{f}$ illustrate scatterplots of the leading air constituent-meteorology interrelationships are listed in Table 3. The CO scatterplot (cf. Figure 8b) is more coherent at low concentrations, corresponding with high humidity and wet deposition. A key feature is the insensitivity of methane concentrations to meteorological forcing.

\subsection{Meteorology of trace gas episode}

The $\mathrm{NO}_{2}$ episode of 24-26 December 2010 (Figures 9a-c) features dry anticyclonic easterly flow that slows abruptly on reaching the Rift Escarpment, creating a calm area over the central highlands of Ethiopia. The HYSPLIT simulation shows trace gas accumulation in the wind shadow to the west of the mountains. Radiosonde profiles over Arabia measured low dewpoint temperature $\left(-30^{\circ} \mathrm{C}\right.$ at $800 \mathrm{hPa}$ ) under westerly flow. CALIPSO aerosol sections and corresponding atmospheric circulation features during this event (Figure 9c) illustrate subsidence above the PBL along the edge of the subtropical jet stream. The top of the dense aerosol layer rises over the highlands but is constrained by meridional rotors on either side. The upper-level anticyclonic vorticity induces midlevel sinking motion and near-surface drying. The key feature of the episode is a deflection of stable easterly flow on reaching the Rift Escarpment. The consequent wind shadow acts like a magnet for trace gases from diverse sources.

\section{Concluding discussion}

This study advances our understanding of agricultural emissions that contribute to greenhouse warming using satellite estimates of key air constituents and, thus, has broad relevance to the wider scientific community.

The air chemistry of Ethiopia has been studied using seasonal and daily satellite estimates and inventory-based model products in the period $2000-16 . \mathrm{CH}_{4}$ reaches 
Earth Interactions - Volume 22 (2018) • Paper No. 12 • Page 16
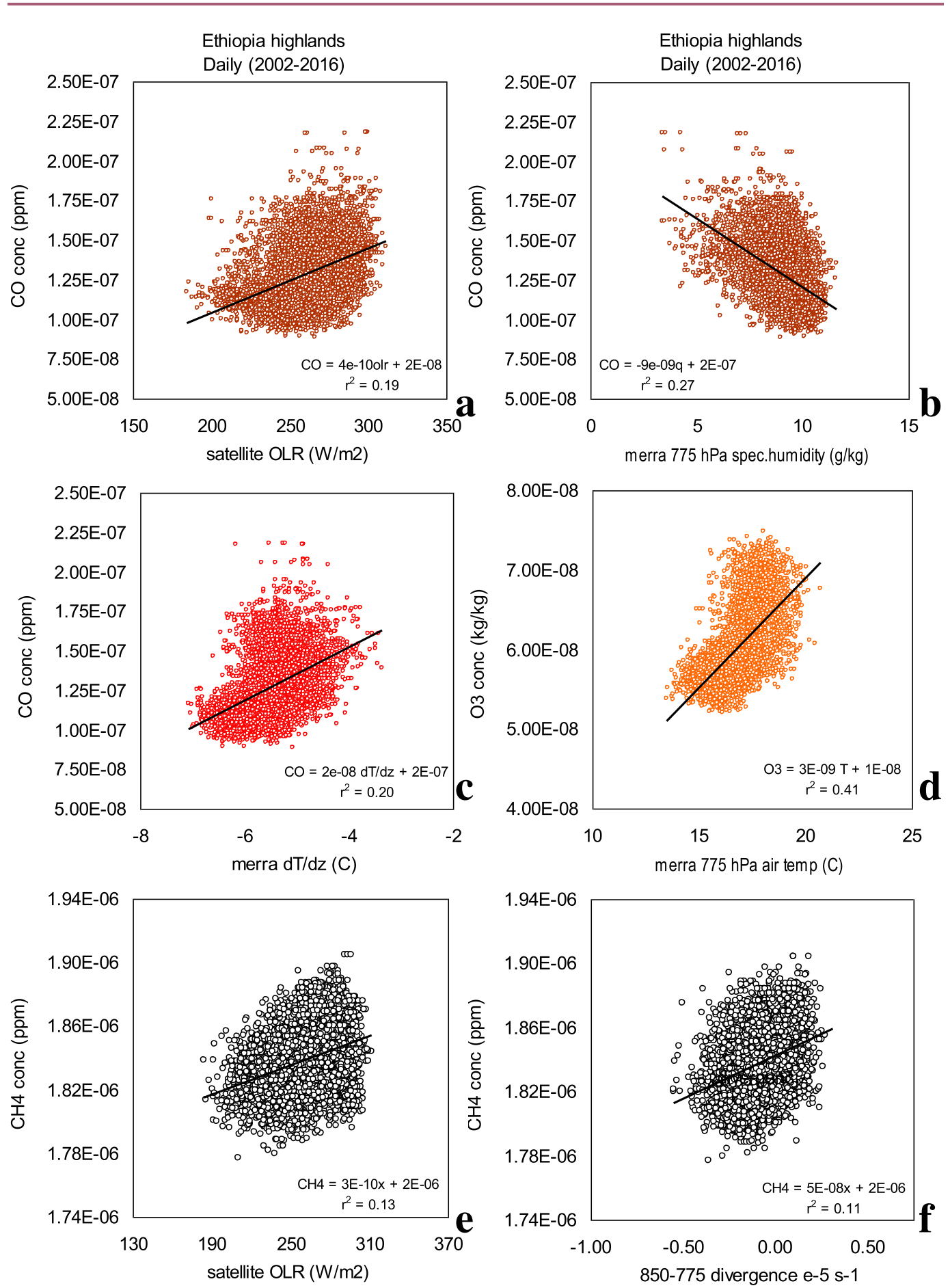

Figure 8. Scatterplots of daily time series comparing meteorology and air constituents averaged over the Ethiopia index area: (a) OLR vs CO, (b) specific humidity vs $\mathrm{CO}$, (c) $d T / d z$ vs $\mathrm{CO}$, (d) air temperature vs $\mathrm{O}_{3}$, (e) OLR vs $\mathrm{CH}_{4}$, and ( $f$ ) wind divergence vs $\mathrm{CH}_{4}$. Linear fit is given; daily correlations are listed in Table 3. 


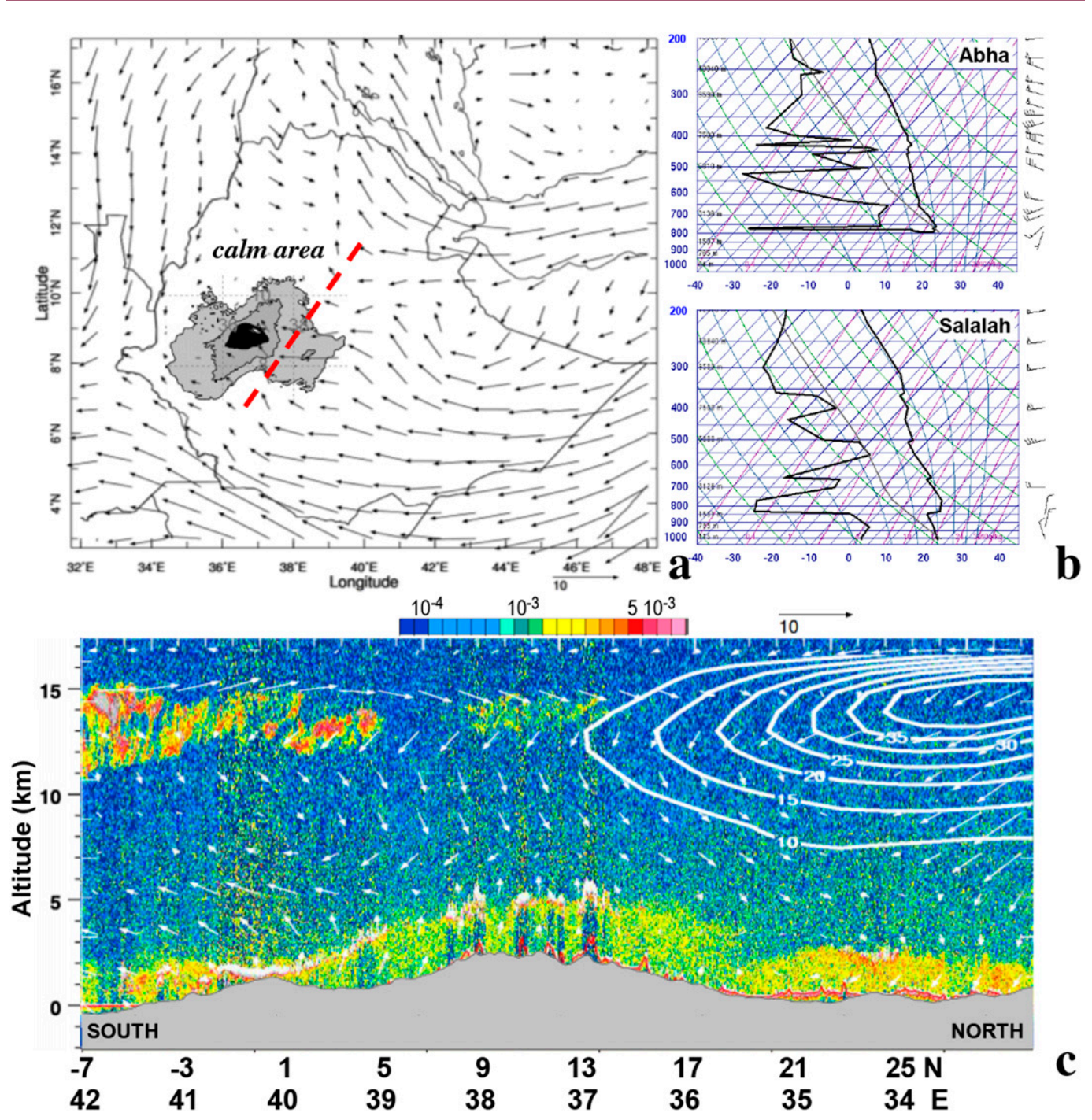

Figure 9. (a) HYSPLIT simulated dispersion (shaded 0.1, 1, $10 \times 10^{-6} \mathrm{~kg} \mathrm{~m}^{-3}$ ) 24-26 Dec 2010 from $9^{\circ} \mathrm{N}, 37^{\circ} \mathrm{E}$, near-surface wind (vectors); dashed red line highlights the wind barrier. (b) Arabian radiosonde profiles of temperature, dewpoint, and wind at 0000 UTC 25 Dec 2010. (c) CALIPSO aerosol density at 1400 UTC 24 Dec 2010, with wind circulation (meridional vectors and zonal contours $>10 \mathrm{~m} \mathrm{~s}^{-1}$ ) and topography overlay.

high concentrations due to livestock emissions over the north-central highlands and is above the global average from November to March (cf. Figure 4b). In contrast, $\mathrm{CO}$ rises over the western highlands in the dry season. Among the seasonal cycle correlations, dust, $\mathrm{AOD}$, and $\mathrm{CO}_{2}$ are inversely related with $\mathrm{CH}_{4}$; $\mathrm{BC}$ and $\mathrm{CO}$ are negatively related with humidity and rainfall; and $\mathrm{CO}$ closely follows SHF, indicating that drier conditions favor biomass burning. Northerly (southerly) winds enhance $\mathrm{CO}_{2}(\mathrm{BC})$, and westerly winds enhance AOD, whereas easterly winds drive up $\mathrm{CO}, \mathrm{CH}_{4}$, and $\mathrm{O}_{3}$. Hence, the slowly varying seasonal circulation and 


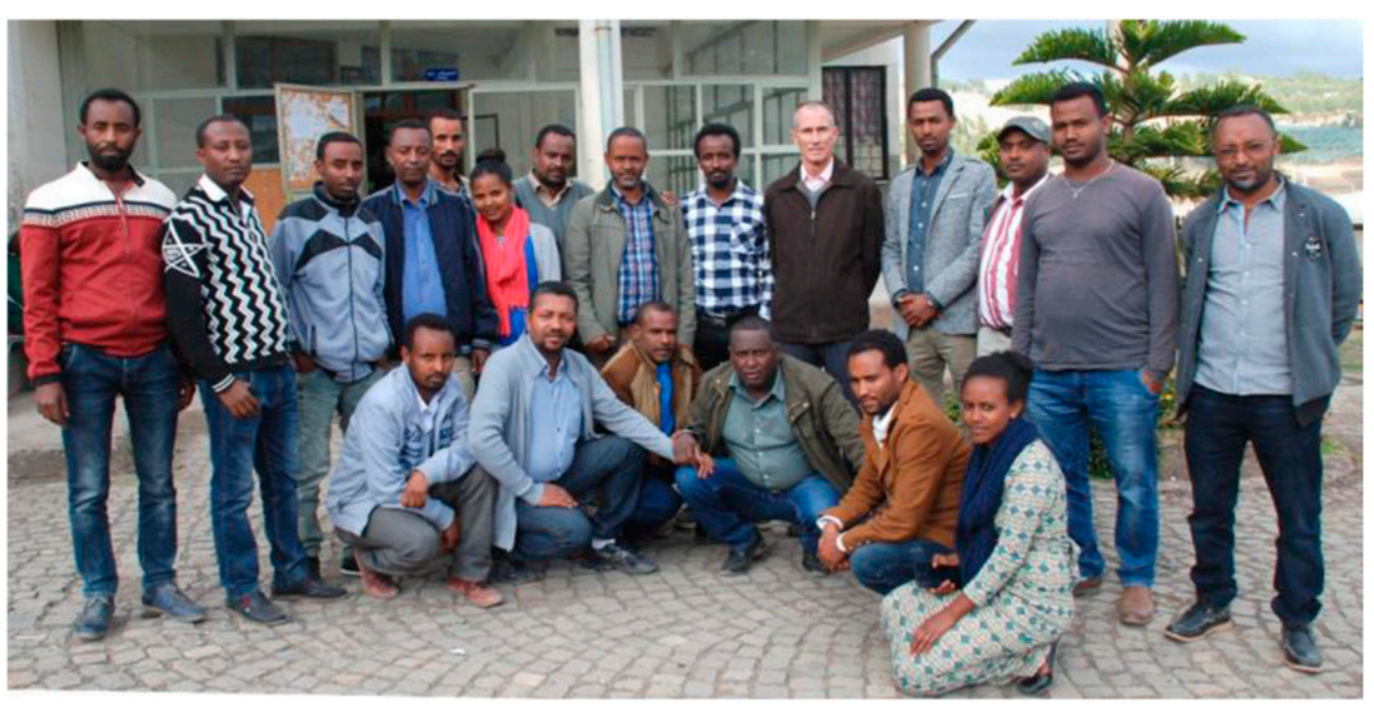

Figure A1. Participants in the Wollo University air chemistry and meteorology data analysis workshop, 16 Dec 2016.

agricultural land-use underlie short-term weather fluctuations, which collectively determine trace gas concentrations.

Daily correlations reveal interdependence of $\mathrm{CO}$ and $\mathrm{NO}_{2}$ and of meteorological sensitivity to dry, stable weather conditions and anticyclonic easterly winds that create a calm area next to the Rift Escarpment. $\mathrm{CH}_{4}$ fluctuations are relatively insensitive to weather conditions, whereas near-surface $\mathrm{O}_{3}$ increases with air temperature. Dispersion conditions underlying high $\mathrm{CO}, \mathrm{CH}_{4}$, and $\mathrm{NO}_{2}$ episodes are characterized by stable, dry, anticyclonic weather and midtropospheric subsidence from intrusion of the northern subtropical jet stream. The circulation and trace gas patterns suggest that many GHGs are locally generated, not imported. The wind shadow cast by the Rift Escarpment accumulates emissions such as $\mathrm{CH}_{4}$, which has increased $>0.1 \mathrm{ppm}$ from 2002 to 2016. Its linear upward trend accounts for $43 \%$ of variance and suggests the need to improve the efficiency of livestock production in Ethiopia. Future work will compare new in situ data with satellite retrievals.

Acknowledgments. The author gained valuable insights working in Ethiopia with Wollo University (appendix photo), Arba Minch University, and the Melkasa Institute for Agriculture Research, with support from the South African Department of Education. Some data analyses derive from NASA Giovanni, IRI Climate Library, APDRC Hawaii, NOAA ARL Ready, University of Wyoming radiosonde, and KNMI Climate Explorer. E. A. Marais of the University of Birmingham provided useful insights during preparation of the manuscript.

\section{Appendix}

Figure A1 is a photo of participants in the Wollo University air chemistry and meteorology data analysis workshop on 16 December 2016. 
Earth Interactions - Volume 22 (2018) • Paper No. 12 • Page 19

\section{References}

Abate, Z., 2015: Impact of vehicle emission on air pollution in Addis Ababa. Stakeholder Workshop on Air Quality and Transportation Challenges in Ethiopia and Agenda for Clean Air Action Plan, Addis Ababa, Ethiopia, Ministry of Environment and Forest, The Federal Democratic Republic of Ethiopia and Centre for Science and Environment, 8 pp., www.cseindia.org/ userfiles/ethiopia-report.pdf.

Andreae, M. O., and V. Ramanathan, 2013: Climate's dark forcings. Science, 340, 280-281, https:// doi.org/10.1126/science.1235731.

Arino, O., S. Casadio, and D. Serpe, 2012: Global night-time fire season timing and fire count trends using the ATSR instrument series. Remote Sens. Environ., 116, 226-238, https://doi.org/ 10.1016/j.rse.2011.05.025.

Bergamaschi, P., and Coauthors, 2007: Satellite chartography of atmospheric methane from SCIAMACHY on board ENVISAT: 2. Evaluation based on inverse model simulations. $J$. Geophys. Res., 112, D02304, https://doi.org/10.1029/2006JD007268.

Broucek, J., 2014: Production of methane emissions from ruminant husbandry: A review. J. Environ. Prot., 5, 51796, https://doi.org/10.4236/jep.2014.515141.

Buchard, V., and Coauthors, 2015: Using the OMI aerosol index and absorption aerosol optical depth to evaluate the NASA MERRA Aerosol Reanalysis. Atmos. Chem. Phys., 15, 57435760, https://doi.org/10.5194/acp-15-5743-2015.

Bucsela, E. J., and Coauthors, 2013: A new stratospheric and tropospheric $\mathrm{NO}_{2}$ retrieval algorithm for nadir-viewing satellite instruments: Applications to OMI. Atmos. Meas. Tech., 6, 26072626, https://doi.org/10.5194/amt-6-2607-2013.

Burrows, J. P., U. Platt, and P. Borrell, Eds., 2011: The Remote Sensing of Tropospheric Composition from Space. Springer-Verlag, $536 \mathrm{pp}$.

CAIT, 2016: Country GHG emissions. World Resources Institute Agricultural Emission Database, CAIT Climate Data Explorer, https://cait.wri.org/profile/Ethiopia.

Cecil, D. J., D. E. Buechler, and R. J. Blakeslee, 2015: TRMM LIS climatology of thunderstorm occurrence and conditional lightning flash rates. J. Climate, 28, 6536-6547, https://doi.org/ 10.1175/JCLI-D-15-0124.1.

Christian, H. J., and Coauthors, 2003: Global frequency and distribution of lightning as observed from space by the Optical Transient Detector. J. Geophys. Res., 108, 4005, https://doi.org/ 10.1029/2002JD002347.

Cooper, O. R., and Coauthors, 2014: Global distribution and trends of tropospheric ozone: An observation-based review. Elem. Sci. Anthropocene, 2, 29, https://doi.org/10.12952/ journal.elementa.000029.

da Silva, A. M., C. A. Randles, V. Buchard, A. Darmenov, P. R. Colarco, and R. Govindaraju, 2015 : The MERRA Aerosol Reanalysis. GMAO Tech. Rep. 7, 30 pp.

Dentener, F., D. Stevenson, J. Cofala, R. Mechler, M. Amann, P. Bergamaschi, F. Raes, and R. Derwent, 2005: The impact of air pollutant and methane emission controls on tropospheric ozone and radiative forcing: CTM calculations for the period 1990-2030. Atmos. Chem. Phys., 5, 1731-1755, https://doi.org/10.5194/acp-5-1731-2005.

Desalegn, T., F. Cruz, M. Kindu, M. B. Turrión, and J. Gonzalo, 2014: Land-use/land-cover (LULC) change and socioeconomic conditions of local communities in the central highlands of Ethiopia. Int. J. Sustain. Dev. World Ecol., 21, 406-413, https://doi.org/10.1080/13504509.2014.961181.

Fantaye, K. T., 2016: Description of cropping systems, climate, and soils in Ethiopia. Global Yield Gap Atlas, www.yieldgap.org/ethiopia.

FAOSTAT, 2016: Ethiopia. Food and Agriculture Organization of the United Nations, accessed December 2016, http://www.fao.org/faostat/en/\#country/238.

Farahat, A., 2016: Air pollution in the Arabian Peninsula (Saudi Arabia, the United Arab Emirates, Kuwait, Qatar, Bahrain, and Oman): Causes, effects, and aerosol categorization. Arab. J. Geosci., 9, 196, https://doi.org/10.1007/s12517-015-2203-y. 


\section{Earth Interactions • Volume 22 (2018) • Paper No. 12 • Page 20}

FAS, 2016: Eastern Africa. U.S. Foreign Agriculture Service, www.pecad.fas.usda.gov/ cropexplorer/imageview.aspx?regionid=eafrica.

Frankenberg, C., and Coauthors, 2006: Satellite chartography of atmospheric methane from SCIAMACHY on board ENVISAT: Analysis of the years 2003 and 2004. J. Geophys. Res., 111, D07303, https://doi.org/10.1029/2005JD006235.

Giglio, L., J. Descloitres, C. O. Justice, and Y. J. Kaufman, 2003: An enhanced contextual fire detection algorithm for MODIS. Remote Sens. Environ., 87, 273-282, https://doi.org/ 10.1016/S0034-4257(03)00184-6.

Joyce, R. J., J. E. Janowiak, P. A. Arkin, and P. P. Xie, 2004: CMORPH: A method that produces global precipitation estimates from passive microwave and infrared data at high spatial and temporal resolution. J. Hydrometeor., 5, 487-503, https://doi.org/10.1175/ 1525-7541(2004)005<0487:CAMTPG > 2.0.CO;2.

Jury, M. R., 2000: The dry season climate of tropical southern Africa and implications for pyrogenic emissions. S. Afr. J. Sci., 96, 387-390.

— , 2016: Large-scale features of Africa's diurnal climate. Phys. Geogr., 37, 120-131, https:// doi.org/10.1080/02723646.2016.1163004.

— 2017: Statistics and meteorology of air pollution episodes over the South African Highveld based on satellite-model datasets. J. Appl. Meteor. Climatol., 56, 1583-1594, https://doi.org/ 10.1175/JAMC-D-16-0354.1.

Justice, C. O., and Coauthors, 2002: The MODIS fire products. Remote Sens. Environ., 83, 244262, https://doi.org/10.1016/S0034-4257(02)00076-7.

Knippertz, P., and M. C. Todd, 2012: Mineral dust aerosols over the Sahara: Meteorological controls on emission and transport and implications for modeling. Rev. Geophys., 50, RG1007, https://doi.org/10.1029/2011RG000362.

Krotkov, N. A., S. Carn, A. Krueger, P. Bhartia, and K. Yang, 2006: Band residual difference algorithm for retrieval of $\mathrm{SO}_{2}$ from the Aura Ozone Monitoring Instrument (OMI). IEEE Trans. Geosci. Remote Sens., 44, 1259-1266, https://doi.org/10.1109/TGRS.2005.861932.

—_, and Coauthors, 2016: Aura OMI observations of regional $\mathrm{SO}_{2}$ and $\mathrm{NO}_{2}$ pollution changes from 2005 to 2015. Atmos. Chem. Phys., 16, 4605-4629, https://doi.org/ 10.5194/acp-16-4605-2016.

Lamarque, J.-F., and Coauthors, 2010: Historical (1850-2000) gridded anthropogenic and biomass burning emissions of reactive gases and aerosols: Methodology and application. Atmos. Chem. Phys., 10, 7017-7039, https://doi.org/10.5194/acp-10-7017-2010.

Lamsal, L. N., and Coauthors, 2014: Evaluation of OMI operational standard $\mathrm{NO}_{2}$ column retrievals using in situ and surface-based $\mathrm{NO}_{2}$ observations. Atmos. Chem. Phys., 14, 11 587-11 609, https://doi.org/10.5194/acp-14-11587-2014.

Landrigan, P. J., and Coauthors, 2018: The Lancet Commission on pollution and health. Lancet, 391, 462-512, https://doi.org/10.1016/S0140-6736(17)32345-0.

Levy, R. C., S. Mattoo, L. A. Munchak, L. A. Remer, A. M. Sayer, F. Patadia, and N. C. Hsu, 2013: The Collection 6 MODIS aerosol products over land and ocean. Atmos. Meas. Tech., 6, 29893034, https://doi.org/10.5194/amt-6-2989-2013.

Maddy, E. S., C. D. Barnet, M. Goldberg, C. Sweeney, and X. Liu, 2008: $\mathrm{CO}_{2}$ retrievals from the Atmospheric Infrared Sounder: Methodology and validation. J. Geophys. Res., 113, D11301, https://doi.org/10.1029/2007JD009402.

Marais, E. A., D. J. Jacob, A. Guenther, K. Chance, T. P. Kurosu, J. G. Murphy, C. E. Reeves, and H. O. Pye, 2014a: Improved model of isoprene emissions in Africa using Ozone Monitoring Instrument (OMI) satellite observations of formaldehyde: Implications for oxidants and particulate matter. Atmos. Chem. Phys., 14, 7693-7703, https://doi.org/ 10.5194/acp-14-7693-2014.

— ozone pollution: A view from space. Atmos. Environ., 99, 32-40, https://doi.org/10.1016/ j.atmosenv.2014.09.055. 
Earth Interactions - Volume 22 (2018) • Paper No. 12 • Page 21

Molod, A., L. Takacs, M. Suarez, and J. Bacmeister, 2015: Development of the GEOS-5 atmospheric general circulation model: Evolution from MERRA to MERRA2. Geosci. Model Dev., 8, 1339-1356, https://doi.org/10.5194/gmd-8-1339-2015.

Piketh, S. J., H. J. Annegarn, and P. D. Tyson, 1999: Lower tropospheric aerosol loadings over South Africa: The relative contribution of aeolian dust, industrial emissions, and biomass burning. J. Geophys. Res., 104, 1597-1607, https://doi.org/10.1029/ 1998JD100014.

Reisner, J. M., and P. K. Smolarkiewicz, 1994: Thermally forced low Froude number flow past three-dimensional obstacles. J. Atmos. Sci., 51, 117-133, https://doi.org/10.1175/ 1520-0469(1994)051<0117:TFLFNF $>2.0$. CO;2.

Rienecker, M. M., and Coauthors, 2016: The GEOS-5 data assimilation system-Documentation of versions 5.0.1, 5.1.0, and 5.2.0. NASA Tech. Rep. NASA/TM-2007-104606, https://gmao. gsfc.nasa.gov/pubs/docs/GEOS-5.0.1_Documentation_r3.pdf.

Robinson, T. P., and Coauthors, 2014: Mapping the global distribution of livestock. PLOS ONE, 9, e96084, https://doi.org/10.1371/journal.pone.0096084.

Tefera, W., A. Asfaw, F. Gilliland, A. Worku, M. Wondimagegn, A. Kumie, J. Samet, and K. Berhane, 2016: Indoor and outdoor air pollution-related health problems in Ethiopia: Review of related literature. Ethiop. J. Health Dev., 30, 1-12.

Teferi, E., W. Bewket, S. Uhlenbrook, and J. Wenninger, 2013: Understanding recent land use and land cover dynamics in the source region of the Upper Blue Nile, Ethiopia: Spatially explicit statistical modeling of systematic transitions. Agric. Ecosyst. Environ., 165, 98-117, https:// doi.org/10.1016/j.agee.2012.11.007.

Thonat, T., C. Crevoisier, N. A. Scott, A. Chédin, T. Schuck, R. Armante, and L. Crépeau, 2012: Retrieval of tropospheric CO column from hyperspectral infrared sounders-Application to four years of Aqua/AIRS and MetOp-A/IASI. Atmos. Meas. Tech., 5, 2413-2429, https:// doi.org/10.5194/amt-5-2413-2012.

Torres, O., P. K. Bhartia, J. R. Herman, A. Sinyuk, P. Ginoux, and B. Holben, 2002: A long-term record of aerosol optical depth from TOMS observations and comparison to AERONET measurements. J. Atmos. Sci., 59, 398-413, https://doi.org/10.1175/1520-0469(2002)059<0398: ALTROA $>2.0 . \mathrm{CO} ; 2$.

Tucker, C. J., J. E. Pinzon, M. E. Brown, D. A. Slayback, E. W. Pak, R. Mahoney, E. F. Vermote, and N. El Saleous, 2005: An extended AVHRR 8-km NDVI dataset compatible with MODIS and SPOT vegetation NDVI data. Int. J. Remote Sens., 26, 4485-4498, https://doi.org/10.1080/ 01431160500168686.

UNDP, 2011: Ethiopia's climate-resilient green economy: Green economy strategy. UNDP Tech. Rep., 200 pp., www.undp.org/content/dam/ethiopia/docs/Ethiopia\%20CRGE.pdf.

USAID, 2013: Agricultural growth project-Livestock market development. USAID Rep. AID663-C-12-00009, 160 pp., https://www.usaid.gov/sites/default/files/documents/1860/AGPLMD\%20Value\%20Chain\%20Analysis.pdf.

van der A, R. J., H. J. Eskes, K. F. Boersma, T. P. C. van Noije, M. Van Roozendael, I. De Smedt, D. H. M. U. Peters, and E.W. Meijer, 2008: Trends, seasonal variability and dominant $\mathrm{NO}_{\mathrm{x}}$ source derived from a ten year record of $\mathrm{NO}_{2}$ measured from space. J. Geophys. Res., 113, D04302, https://doi.org/10.1029/2007JD009021.

van Wesenbeeck, C. F. A., M. A. Keyzer, and M. Nubé, 2009: Estimation of undernutrition and mean calorie intake in Africa: Methodology, findings and implications. Int. J. Health Geogr., 8, 37, https://doi.org/10.1186/1476-072X-8-37.

Warner, J. X., Z. Wei, L. L. Strow, C. D. Barnet, L. C. Sparling, G. Diskin, and G. Sachse, 2010: Improved agreement of AIRS tropospheric carbon monoxide products with other EOS sensors using optimal estimation retrievals. Atmos. Chem. Phys., 10, 9521-9533, https://doi.org/ 10.5194/acp-10-9521-2010.

WHO, 2016: WHO global urban ambient air pollution database. WHO, accessed December 2016, www.who.int/phe/health_topics/outdoorair/databases/cities/en/. 
Earth Interactions - Volume 22 (2018) - Paper No. 12 • Page 22

Winker, D. M., W. M. Hunt, and M. J. McGill, 2007: Initial performance assessment of CALIOP. Geophys. Res. Lett., 34, L19803, https://doi.org/10.1029/2007GL030135.

Wint, W., and T. Robinson, Eds., 2007: Gridded Livestock of the World (GLW). Food and Agriculture Organization Rep., 131 pp.

World Bank, 2016: Ethiopia statistical database. The World Bank, accessed December 2016, https://data.worldbank.org/country/Ethiopia.

Xiong, X., C. Barnet, E. Maddy, C. Sweeney, X. Liu, L. Zhou, and M. Goldberg, 2008: Characterization and validation of methane products from the Atmospheric Infrared Sounder (AIRS). J. Geophys. Res., 113, G00A01, https://doi.org/10.1029/2007JG000500.

Yienger, J. J., and H. Levy, 1995: Empirical model of global soil-biogenic $\mathrm{NO}_{\mathrm{x}}$ emissions. $J$. Geophys. Res., 100, 11 447-11 464, https://doi.org/10.1029/95JD00370.

Yurganov, L. N., W. W. McMillan, A. V. Dzhola, E. I. Grechko, N. B. Jones, and G. R. van der Werf, 2008: Global AIRS and MOPITT CO measurements: Validation, comparison, and links to biomass burning variations and carbon cycle. J. Geophys. Res., 113, D09301, https://doi.org/ 10.1029/2007JD009229.

Earth Interactions is published jointly by the American Meteorological Society, the American Geophysical Union, and the Association of American Geographers. For information regarding reuse of this content and general copyright information, consult the AMS Copyright Policy (www.ametsoc.org/PUBSReuseLicenses). 